\title{
3. Juliusz Jundziłł, Pieniądz w łacińskiej literaturze chrze- ścijańskiej późnego cesarstwa rzymskiego, SACh 3, Warszawa 1984, ATK, S. 254.
}

Nie trzeba przekonywać historyków społecznych i gospodarczych, że pisma ojców Kościoła to świetne, bogate w informacje źródło wiedzy o czasach późnorzymskich. Mimo to bywają one wykorzystywane w ich pracach tylko cząstkowo, wyrywkowo, a przyczyny tego szukałbym nie w lekceważeniu źródła, lecz właśnie w obfitości tekstów, których badanie wymara znacznego nakładu pracy $i$ podstawowych choćby kompetencji w tak wyspecjalizowanej gałęzi wiedzy, jaką jest patrologia. Wypada zatem cieszyć się, że jeden z polskich historyków starożytnych podjął trud ogromnej kwerendy 1 zgromadzenia wzmianek na temat pieniądza i gospodarki pienięznej rozsianych w lacińskiej literaturze patrystycznej IV - V wieku. J. Jundziłł wykonał imponującą pracę poszukując takicin wzinianek w setkach dzieł ok. 80 autorów i zgromadził materiał znacznie wzbogacający naszą wiedze o okresie 1 problematyce niedostatecznie, jak wiadomo, naświetlonych przez inne rodzaje źródeł.

Praca J. Jundziłła jest więc przede wszystkim "thesaurusem" wzmianek źródłowych, ułatwiającym bardzo pracę badawczą innym historykom pieniądza. Jej wartość nie sprowadza się jednak wyłącznie do tej służebnej roli, jako że Autor, jak przystało na ambitnego badacza, systematyzuje materiał 1 stara się go interpretować w celu uściślenia lub skorygowania naszej wiedzy, podejnując przy tym dyskusję z poglądami innych uczonych. Interesujaz go trzy grupy zagadnień: pierwsza z nich, niezbędna dla prawidłowego rozumienia tekstów, to terminologia stosowana przez ojców Kościoła wobec różnych rodzajów pieniądza; kwestia druga, to wyłaniający się z pism łacińskich ojców obraz gospodarki pieniężnej, a w pewnej mierze ocena całej gospodarki późnorzymskiej; wreszcie kwestia trzecia, to stosunek omawianych pisarzy do pieniłquza, szczególnie jego ocena moralna.

W moim przekonaniu właśnie ustalenia Autora w tej ostatniej kwesti1, stanowiącej przedmiot III części pracy, zasługują na największą uwage. J. Jundziłł ukazuje czasową i przestrzennił dynamikę poglądów, poczynając od niewielkiego zainteresowanta problematykaz pieniądza przed św. Ambrozyrn,do żyej dyskusji na jego temat w okresie przeł. IV-V wicku. Wływ tendencji ascetycznych i rozwój rucinu monastycznego spowodowały narastanie posiawy krytycznej. Szczególnie 
ostra jest ona wg Autora u św. Hieronima i pewnych pisarzy galijskich, natomiast zastanawiająco umiarkowany 1 , rzec moźna, realistyczny jest ton pisarzy italskich, szczególnie związanych z Rzymem. Interesująco zbieżna wydaje się ta konkluzja z tezami Cz. Bartnika na temat specyfiki intelektualnej ośrodka papieskiego owych czasów.

Najbogatsza w informacje i najobszerniejsza objętościowo jest II część pracy poświęcona miejscu pieniądza w całej gospodarce cesarstwa. Autor naświetla wiej wiele zagadnień szczegółowych: wymianę handlową, operacje pieniężne, rolę pieniądza w funkcjonowaniu państwa i Kościoła, a także majątków prywatnych, zastanawia się nad stopniem "upienięznienta" ekonomiki rodzajem użyanego pien1ądza 1 jego docieraniem do rónych warstw społecznych. T trakcie czytania tej części rozprawy nietrudno dostrzec, ze nurtują go pytania głębszej natury - w gospodarce pieniężnej widzi odbicie ogólnego stanu gospodarki: jej stabilności, ruchu cen i zamożności ludzi; wypowiedzi na ten temat rozsiane są $w$ całym tekście pracy, wracają też $w$ podsumowaniu. Mamy więc do czynienia z kolejnym głosem $w$ toczonej od wieków dyskusji nad przyczynami upadku cesarstwa rzymskiego. W sporze tym podstawowe znaczenie ma wszak pytanie: czy gospodarka późnorzymska znajdowała sie w stanie kryzysu, czy też przeciwnie rozwijała się prawidłowo, a klęskę państwa spowodowały czynniki zewnętrzne 1 w duzej mierze przypadkowe, jakimi były najazdy. Powyższe sformułowanie znacznie oczywiście upraszcza całe zagadnienie, chodzi jednak o uświadomienie sobie, jak waźne dla podstawowych problemów historycznych maja tak specjalistyczne z pozoru prace, jak rozprawa J. Jundziłła. On sam na temat upadku cesarstwa bezpośrednio się zresztą nie wypowiada.

Ocena gospodarki późnorzymskiej w omawianej pracy wypada zdecydowanie korzystnie, co widoczne jest przede wszystkim w dużym zasięgu obrotu pienięźnego. Pisma ojców Kościoła dostarczają przykładów stosowania go zarówno w wielkich ośrodkach handlowych, jak 1 na prowincji, przez ludzi bogatych jak też 1 biednych, w funkcjonowaniu organów panstwowych 1 w życiu os b́b prywatnych. Wymianę naturalną, która liczni badacze współcześni uważają za typowy w okresie późnego cesarstwa przejaw regresu ekonomicznego, potwierdza Autor wie11cznych tylko przypadkach. Tu jednak nasuwa się pewna wątpliwość. Praca została oparta na analizie wzmianek mówiqucych o pieniądzu, nie zaś na wzmiankach mówiących o wszelkim obrocie dóbr materialnych, czy 
zatem uzyskany obraz pozwala na obiektywne porównanie? Zresztą czasem miałbym wątpliwości, czy przytaczane teksty dają pewność, że mamy do czynienia z uźyciem pieniądza. Pozwolę sobie zwrócić uwage na kilka przykładów tego typu: kradzież ołowianej balustrady, choćby wartościowej/s. 88-89/ nie oznacza, że złodziej cheiał ją sprzedać za pieniądze. Zatrudniano w dobrach często dispensatora /s. 94-95/, co oznaczało duży obrót pieniężny, ale przy założeniu, że dominowała w nich gospodarka pieniężna - jeśli bowiem tak nie było, to zapewne dispensator miał nie mniej zajęcia, prowadząc rachunkowość bez pieniędzy, kto wie, czy nie bardziej jeszcze rozbudowana. Wreszcie pojawiające się w źródłach informacje o cenie lub wartości, podawane w jednostkach pieniężnych, nie dowodzą faktycznego uźycia pieniądza przy ich wymianie, choć pieniądz pełni tu swoistą 1 bardzo istotna funkcję miernika wartości.

Należy podkreślić, że mówiąc o IV i V wieku nie rozważamy alternatywy: gospodarka pieniezzna czy gospodarka naturalna, gdyż elementy jednej $i$ drugiej występowały równocześnie. Chodzi o ustalenie, które elementy przeważały. J. Jundziłł jest tego oczywiście świadom, skoro przykładowo na s. 120 pisze o dominacji pieniądza w dobroczynności kościelnej - dominacji, więc nie wyłączności. Gospodarka pienięźna późnego cesarstwa wykazywała jednak pewne niedoskonałości dowodzące niższeso poziomu w porównaniu z okresami wcześniejszymi lub późniejszymi. W, literaturze badawczej zwraca się na przykład uwagę na pewien niedorozwój bankowości. Numizmatycy z kolei stwierdzaja wadlixość systemu monetarnego, widoczną przede wszystkim w braku średnich nominałów, zaś w wieku V w zmniejszeniu ich 1iczby。 Podejrując dyskusję z taką oceną J. Jundziłł zwraca uwagę na to, że w swietle literatury patrystycznej noneta złota miała bardzo szeroki zasięg społeczny: używali jej nawet ubodzy mnisi /s. 191/. To bardzo interesująca konstatacja dowodząca, że nawet w transakcjach óredniej wielkości używano pieniądza, ale czyniono to zapewne $z$ pewnym trudem. Poprawę sytuacji przyniosły dopiero reformy monetarne końca $V$ wieku.

Za przejaw niestabilności gospodarki uchodzi zwykle nie dający się opanować ruch cen. W oparciu o wamianki w pismach zachodnich ojców, wykorzystując jednak równieź dane z innych źródeł, dochodzi Autor do wriosku, że ceny były w IV - V w. stosunkowo stabilne, a nawet daje się zauważyé niewielki ich spadek /s. 193/, czego przykładem są umiarkowane ceny niewolników/s. 228/. Istot- 
nie, ten rodzaj "towaru" mógł w okresie najazdów 1 wojen potanieć, co jednak o stanie gospodarki nie wydaje się najlepiej świadczyć. Opinia o ruchu cen byłaby bardziej przekonywująca, gdyhy poparto ją pełnym zestawieniem materiału przeliczonego w jednostkach porównywalnych. Na s. 193 Autor nie określa, czy stabilne były ceny w solidach, czy monetach brazowych. Na s. 104 podano ceny usług Pryzjerskich w denarach sugerując, że w ciągu ponad 100 lat nie uległy one większym zmianom. Pozostaje jednak pytanie, czy wartość jednostki pleniężnej nie uległa wzrostowi. Autor zdaje się powątpiewać w duże rozmiary późnorzymskiej inflacji pieniądza brązowego, twierdząc, że tezę o jej rozmiarach wysunięto głównie w oparciu o dane numizmatyczne/s. 104 przyp. 92/. Można się zgodzić, że samo zmniejszanie się wagi monet nie musi byé wynikiem inflacji /s. 192/, ale za taką interpretacją przemawiają równieź inne źródła. Zresztą zaproponowane na s. 192 wyjaśnienie owego spadku wagi monet, jako rezultatu wzrostu "roli pracy najemnej oraz wytwórczości drobnotowarowej" nie za bardzo przekonuje. Jési dobrze rozumiem nader lakonicznie sformułowana hipotezę Autora, to w V w. miała wzrosnąć liczba transakcji drobnych, w związku z czym zaczęto emitowanie dużej ilości brązowych "minimi". Pozostaje jednak pytanie, dlaczego równocześnie znikły nominały większe - czyżby zanikł ten typ transakcji, w których były stosowane? Bardziej prawdopodobne wydaje się, ze transakcje były podobne, za to monety nniejsze. Oczywíscie bicie lżejszej monety nie jest równoznaczne z inflacją, choć pośrednio z nią się łączy. Nie wdając się w dalsze szczegółowe dywagacje, które znaleźć można w opracowaniach specjalistycznych, pozwolę sobie stwierdzić, że w gospodarce pieniężnej, szczególnie w dziedzinie pieniądza brązowego, zaznaczyły się w IV - V w. pewne niekorzystne tendencje $i$ jeśli przetrwała ona do końca $V$ w., to dowodzi to, że była silnie zakorzeniona w społeczeństwie rzymskim. Jak widać z powyższej konkluzji, podzielam stanowisko

J. Jundziłła w kwestii zasadniczej - uznaję duże znaczenie gospodarki pieniężnej w epoce późnego cesarstwa, nie sądzę też, by okres ten oznaczał jakieś radykalne cofnięcie się ekonomiki w porównaniu z cesarstwem wczesnym, jestem jednak mniejszym optymista w ocenie tendencji ekonomicznych, rysujących się w wiekach IV - V, przede wszystkim na terenie prowincji zachodnich, których w przeważającej mierze dotyczy zebrany przez Autora materiał. 
Rozdział I dotyczący terminologii, omawiam na końcu, zdaje sobie bowiem sprawę z tego, że jego tematyka może zainteresować dość ograniczone grono specjalistów - numizmatyków lub językoznawców. Dla innycin czytelników istotne będzie raczej zagadnienie ogólne: czy teksty patrystyczne moga być pomocne do ustalania danych wymagających wielkiej ścisłości, a dotyczących dziedzin dla ojców Kościoła gruncie rzeczy marginalnych.

Terminy pieniężne dzieli Autor na "biblijne" i współczesne. Pierwsze omawia pobieżnie /poświęcił im osobny artykuł/, bo to problem godny wprawdzie uwagi, ale przyczyniający się w niewielkim stopniu do poznania ekonomiki późnoantycznej. Omówienie współczesnyc terminów zaczyna J. Jundziłł od pieniądza złotego, wspomina tylko ma ginalnie pieniądz srebrny, o którym wzmianki są nieliczne, przecho$\mathrm{dzi}$ nิastępnie do brązów, a na koniec zajmuje się określeniani zbiorczymi. Koncepcja rozdziału jest trafna: szczególnie przydatne przy lekturze są tablice określajqce czas 1 miejsce, do których odnoszą się poszczególne informacje oraz wielkość cytowanych kwot. Bardzlej kontrowersyjne wydaja mi się niektóre interpretacje zawarte w tekście. Z przytoczonych wzmianek u ojców ł́acińskich wynika, że solid /nie widze powodu do stosowania niespolszczonej wersji "solidus"/ określany był także: aureus, nummus aureus /s. 17-18/, co wydaje się całkiem naturalne/Thesaurus Linguae Latinae przytacza dalsze przykłady/ $i$ nie wymaga zawiłych wyjaśnień. Była to nazwa bliżsa tradycji, mniej "techniczna", a więc lepiej nadająca się do uzycia w tekstach literackich. Nie widziałbym $w$ tym nawet przejawu archaiz: cji, gdyz traktowanie aureusa jako dawniejszego nominału/bitego wg stopy $1 / 60$ funta/, przeciwstawionego Konstantyńskiemu solidowi /stopa 1/72 funta/, to rzecz umowna, przyjęta w nowożytnej nauce. Nic dziwnego, że w literaturze greckiej słowo "solidos" jest rzadki powszechnie natomiast stosuje sie "chrysous", "nomisma chrysoun". Interesujące wydają się natomiast rozważania Autora nad terminem "aureus denarius" /s. 18/.

J. Jundziłł stwierdza brak nazw pieniędzy srebrnych "okré́lonego rodzaju" /s. 41 przyp. 60, por. s. 191/w dziełach ojców łaciniskich. Potwierdza to znaną tezę o ograniczonej roli monet z tego kruszcu. Może jednak wartoby było zastanowié się nad odniesieniem do stosunków współczesnych terminu "argenteus" / wzmiankowany tylko na s. 30 przyp. 37/. Roli pieniądza srebrnego nie pełnił oczywiście 
bilon - posrebrzane monety brązowe, które jako ostatni emitował Julian /s. 41 przyp. 60/. Srebrne były millarensy 1 silikwy, które, jak wynika z kwerendy przeprowadzonej przez Autora, pod tą nazwa w źródłach patrystycznych się nie pojawiały.

Terminologia zwiazzana z monetą brązowa/lub bilonowa tj. "srebrno-brązową"/ nastręcza badaczom najwięcej trudności. Nie może ulegać wątpliwości, że szereg określeń przyjmuje więcej niż jedno znaczenie. Zgodnie z konkluzją J. Jundziłła, "nummus" to zarówno mała moneta brązowa, jak 1 moneta w ogóle/nawet złota 1 srebrna/. Z kolei "denar" może być rozumiany jako moneta niedużej wartośc1, albo jednostka obliczeniowa. Relacja wymienna nummusów i denarów nie rysuje się jasno $i$ tu ustalenia zawarte w pracy są tez niezbyt pomocne, Jako że w przedziale 1:2 - 1:23/s. 34-35/ zawiera się nazbyt dużo możliwości. W niektórych tekstach denar 1 nummus zdają się być traktowane równorzędnie, albo na zasadzie retorycznej bez troszczenia się o ścisłość wypowiedzi, albo ze względu na zrównanie wartości obu jednostek w jakimś konkretnym momencie. Wydaje się, ze 1ch relacja ulegała stopniowym zmianom i jeśli dla IV w. H. Mattingly przyjnuje stosunek 1 nummus $=2$ denary $/ \mathrm{s} .27$ przyp. 29/, to wońcu V w. w Afryce stosunek ten zdaniem większości badaczy wynosił 1 denar $=5$ nummi. Zdaje się, że Autor mniejszą wage przywlązuje do tych zmian w czasie, niż do różnic terytorialnych w systemie monetarnym, a raczej w sile nabywczej brazowych pieniędzy. Te jednak różnice należałoby stwierdzić $w$ oparciu o szerszy 1 bardziej konkretny zastaw danych. Ustalenie dużej siły nabywczej "nummusa afrykańskiego" /s. 37, 81/ opiera się na lekcji z Sermo 167 św. Augustyna: "das nummum" / w tekście omyłkowo "nummus", co nie daje sensu/, podczas gdy winno być "das nummos", co bez określenia, o ile nummusów chodzi, unierıżliwia wyliczenie ceny.

Brak ścisłości terminologicznej w odniesieniu do monet $i$ pieniądza nie jest cechą specyficzną literatury patrystycznej. W całym piśmiennictwie późnorzymskim nazwy konkretnych nominałów, które w odróżnieniu od powyższych nie pozwalałyby na wiele interpretacji, np. maiorina, centenionalis $i$ in. pojawiaja się niezwykle rzadko; prawdopodobnie nazwy te nie mogły uchodzić za godne tekstu literackiego. Zresztą dla ścisłego oddania wartości posługiwano się przypuszczalnie raczej jednostkami obliczeniowymi lub wagowymi.o tym, że tak było, śwładczy sposób używania terminu "follis". Lównieź on był 
równocześnie pojmowany jako konkretna moneta 1 jednostka obliczeniowa /co oczywiście nie oznacza, by stanowił synonim denara - /s, 40 przyp. 59/. Przede wszystkim jednak follis to "worek" - odliczona lub odważona ilość pieniędzy opieczętowana $i$ w tej formie stosowana w wymianie. Takie follisy zastępowały monetę średnich nominałów. Mówi o nich np. św. Augustyn w Sermo 178, 7-8/por. s.94/. Jeśl1 więc spotykamy się w jakimś źródle z follisem o wartości 125 millarensów, to jest rzeczą oczywistą, że nie chodzi o monetę/wagi ok. $1 / 2 \mathrm{~kg} ! /$, lecz o taką jednostkę obliczeniową /por. s. 41 przyp. 60/.

W analizowanych tekstach stwierdza Autor pojawianie się zwyczaju stawiania jednostek monetarnych na równi z jednostkami wagowymi /np. św. Augustyn, Ennarrationes in Psalmos 93, 24; por. u Ambrożego, De Abraham 1, 9, 87: "decem aureorum pondus"/. Spotykamy to szczegó1nie w ówczesnych tekstach metrologicznych, czy w napisach. Nie sądzę, by w zwiazku z tą powszechną praktyka konieczne było stawianie problemu pienięźnego charakteru monety kruszcowej. Oczywiście u podłoża liczenia wagi pieniądza w okresie późnorzymskim leżała obawa, że nieuczciwi mincerze mogą zaniżać jego wartość /8. 137 przyp. 141/, z czasem ten sposób traktowania pieniądza stał się jednak całkowicie normalny - w związku z czym numizmatycy mówią o dominowaniu w systemie monetarnym zasady "pełnowartościowości"/ilość kruszcu decyduje o wartości nad zasada nominałowości. Pieniądz pełnowartościowy jest oczywiście także pieniądzem. Wobec takiego charakieru pieniądza, jak też wobec istnienia kilku jego rodzajów, całkowicie naturalnym zjawiskiem był handel pieniądzem /por.s. 191/. Inna natomiast jest wymowa nielicznych wzmianek świadczących o płaceniu kruszcem niemonetarnym. Być może Autor zbyt pośpiesznie interpretuje czasem słowo "aurum" jako złoty kruszec/np.s.97: "nummum vel aurum"/.

Moneta pełnowartościowa był w IV-V w. przede wszystkim solid. Co do monet brązowych można przyjąc, że jeśli nawet nie zawsze, to z pewnością w długich okresach pełniły one rolę pieniądza kredytowego, tj. zdawkowego, posiadającego wartość ustaloną oficjalnie powyżej wartości metalu. Wbrew poglądowi Autora numizmatycy / 1 historycy gospodarczy/, przyjmujący taki właśnie charakter pieniądza brązowego, nie stosuja "minimalistycznej oceny" jego wartości /s. 38 przyp. por. 43\%. Istnienie monety kredytowej nie musi świadczyć o złym stanie gospodark1. Istotna sprawa jest natomiast, czy system monetarny funkcjonował wystarczająco sprawnie, czy moneta była akceptowana 
1 cieszyła się zaufaniem. Wartałoby tu zwrócić uwage na te wypowiedzi Ojców Kościoła, w których jest mowa o zwizzku wyobrażenia cesarskiego na monecie z majestatem władcy. Ciekawe jest też to, że brak jest wypowiedzi kwestionujących pozycję pieniądza i jego siłę nabywczą.

Pewne problemy łączą się z określeniami zbiorczyni, przede wszystikim z terminem "pecunia". J. Jundziłł poddaje w wątpliwość rozpowszechniony w nauce pogląd, iż słowo to w okresie póznorzymskim oznacza "pieniądz brązowy"/s. 43-44/. Przytoczone przez niego przykłady potwierdzają w części utrzymywanie się znaczenia ogólnego "pieniądz". Nie widać jednak przeszkód, by przyjąć, że oba znaczenia występorały równocześnie, podobnie jak dwa/lub więcej/znaczenia takich słów jak "aurum", "argentum". Zdanien Autora na duże rozpowszechnienie u pisarzy chrześcijańskich terminu "pecunia" w sensie "pieniądz"/w ogóle/ wpłynął ustęp z Ewangelii św. Mateusza /Mt 10, 9/, w którym zestawione są "aurum, argentum, pecunia", czyli zdaniem J. Jundziłła "złoto, srebro i pieniądz". Trzeba jednak pamiętać, że w tym ustępie "pecunia" jest tłumaczenien greckiego "chalkón". W sumie nie wydaje mi się rzecza łatwa rozstrzygnięcie w kazdym konkretnym przypadku, czy tam, gdzie występuje określenie "pecunia", mamy do czynienia z "pieniądzem" / ogóle/, czy z "pieniądzem brązowym".

Sądząc z doświadczeń omawianej pracy, rekonstruowanie terminologii pieniężnej, czy systemu monetarnego w oparciu o pisma 0jców Kościoła napotyka na poważne trudności. Bez odwołania się do innych źródeł nie uzyskamy ustaleń pewnych, choć nawet uwzględniając cały materiat ǵródłowy nie rozwiążemy wszystkich wiążących się z tą problematyką dylematów. Większe nađzieje wiązać moźna z oparciem na ana11zie dzieł patrystycznych ogólnej oceny gospodarki późnorzymskiej. $Z$ punktu widzenia metodologicznego jest nawet interesującym zabiegiem przeprowadzenie badań wyłącznie w oparciu o ograniczoną grupę źródeł, a następnie porównanie uzyskanych rezultatów z ustaleniami badá opartych na innym materiale. Bardzo ostrożnie trzeba jednak podejśs do różnic w ustaleniach, gdyż mogą być one spowodowane przez czynniki przypadkowe - w omawianym przypadku: czy optymistyczna ocena gospodariki nie wiqze się ze sposobem postawienia pytań badawczych lub ze specyfiką tekstów patrystycznych. Le zrozumiałych względów najbardziej przydatne są pisma ojców Kościoła do badań nad etyczną oceną gospodurki pienį̨źnej u chrześcijan IV - V wieku. 
Pisząc o pracy J. Jundziłła podniosłem jej aspekty dyskusyjne. Nie oznacza to jednak, bym poddawał w wątpliwość znaczenia 1 pożytki płynące z niej dla nauki. Badania nad późnym antykiem zyskały dzięki niej wiele interesujących informacji źródłowych 1 ustaleń, 1 nawet jeśli część z tych ustaleń spotka się z głosami krytycznymi, to jednak równocześnie skłoni do ponownego przenyślenia rozpowszechnionych w nauce poglądów.

Maciej Salamon - Kraków

4. Ks. Augustyn Eckmann, Dialog świetego Augustyna ze światem pogańsk1m w świetle jego korespondencj1, Lublin 1987, Redakcja Wydawnictw KUL, s. 450.

Lata 1986 i 1987 są szczególnie pobudzające do studiów 1 do ponownego przejrzenia pism wielkiego ojca Kościoła, bo święciliśmy pod przewodem ojca św. Jana Pawła II rocznicę nawrócenia 1 chrztu św. Augustyna. Oprócz wspomnień jubileuszowych otrzymaliśmy w tym czasie równieź naukowa habilitacyjna monografię pod przytoczonym iv nagłówku recenzji tytułem pióra ks. Augustyna Eckmanna. Autor rozprawy zajmował się ową problematyką juź wcześniej w 6 studiach, które wykazały jego wzrastające kompetencje $i$ pogłębione badania myśl1 Biskupa IIippony na wskazanym odcinku. Tym razem łatwo zauważý nowe podejście Autora do zagadnienia dawno budzacego jego zainteresowanie, a mianowicie do dialogu św. Augustyna. Nie rozprawia on o p1smach antypogańskich czy polemicznych, mimo ze owe gatunki nawiązywały do retoryki starożytnej, ale dyskusję z poganami charakteryzuje jako dialog. Bylibyśmy bardzo wdzięczni, gdyby Autor zajaz się dialogiem jako takim w ujęciu swego wielkiego Patrona, tym bardziej, że plerwsze kroki na tya odcinku myśli u innych ojców Kościoła już poczyniono, ale nie przebadano jeszcze pod tym względem Doktora Iaski; właśnie Autor omawianej monografil był szczególnie upravniony do podjęcia się takiego tematu. Zam1ast tego podał on w swej monografil tło dlalogu, przyblizając nas do rzeczywiście prowadzonej dyskusji. W ten oto sposób prezentuje nam Afrykę Północną w epoce punickiej, a co ważniejsze przybliża nas do przeobrażeń religijnych dowodząc, że elementy religijne 1 moralne 1stniejące w religii pogańskiej uwypuklały wartośc1 chrześcijaństwa. Przechodząc następnie do cesarstwa 